\title{
KEPEMILIKAN SAHAM, KEBIJAKAN DIVIDEN, KARAKTERISTIK PERUSAHAAN, RISIKO SISTIMATIK, SET PELUANG INVESTASI DAN KEBIJAKAN HUTANG
}

\section{Yulius Kurnia Susanto}

\author{
STIE Trisakti \\ yulius@stietrisakti.ac.id
}

\begin{abstract}
Abstrak: The purpose of the research was to obtain empirical evidence that managerial and institutional ownership, dividend policy, firm growth, profitability, firm size, systematic risk, investment opportunity set and asset structure affect debt policy. The population in this research are all companies that listed in Indonesia Stock Exchange with the observation period 2005 to 2008. The sample selection was done by using purposive sampling method. Data used in this research was obtained from financial statement and Fact Book, performance summary of listed companies and BAPEPAM-LK. Data analysis used a multiple regression analysis. The results of this research are managerial ownership, cash dividend policy, profitability, firm size, investment opportunity set and asset structure affect debt policy. While the institutional ownership, firm growth and systematic risk not affect debt policy. Manager who owns shares in his company tends to use funds from retained earnings and share capital. They will distribute cash dividends to attract investors to buy shares. Source of funds from obligation providing a risk to the company.
\end{abstract}

Keywords: Debt policy, managerial and institutional ownership, cash dividend policy, firm growth, profitability, firm size, systematic risk, investment opportunity set and asset structure. 


\section{PENDAHULUAN}

Penggunaan modal eksternal yang sering kali digunakan oleh perusahaan, rentan terhadap konflik antara stockholder dan manajemen. Terjadinya konflik yang disebut sebagai agency conflict ini disebabkan karena adanya perbedaan kepentingan antara pihak-pihak terkait (stockholder dan manajer). Agency conflict yang terjadi antara pemegang saham dan manajer menyebabkan timbulnya biaya agensi (agency cost).

Beberapa alternatif yang dapat dilakukan untuk mengurangi agency cost yaitu (1) Dengan cara meningkatkan kepemilikan saham perusahaan oleh pihak manajemen sehingga manajer akan berhati-hati dalam melakukan pengambilan keputusan serta dapat merasakan langsung manfaat dari keputusan yang diambil, (2) Mekanisme pengawasan dalam perusahaan. Salah satu mekanisme pengawasan tersebut adalah dengan meningkatkan monitoring agent oleh institutional investor, (3) Meningkatkan dividend payout ratio. Dengan demikian tidak tersedia cukup banyak free cash flow dan manajemen terpaksa mencari dana dari luar untuk membiayai investasinya, (4) Meningkatkan pendanaan dengan hutang. Peningkatan hutang akan menurunkan agency conflict dan excess cash flow yang ada dalam perusahaan sehingga menurunkan kemungkinan pemborosan oleh manajemen (Murni dan Andriana 2007).

Apabila terjadi peningkatan pertumbuhan yang semakin cepat, hal ini mengindikasikan bahwa perusahaan sedang mengadakan ekspansi. Pengadaan ekspansi ini akan membutuhkan dana yang besar. Untuk itu, manajemen sering kali menggunakan retained earnings yang seharusnya dibagikan kepada stockholders, tetapi karena perusahaan membutuhkan dana dan adanya keuntungan di masa yang akan datang maka dana tersebut digunakan untuk mengembangkan perusahaan.

Tujuan untuk mendapatkan bukti empiris bahwa kepemilikan managerial, kepemilikan institutional, kebijakan dividen kas, pertumbuhan perusahaan, profitabilitas, ukuran perusahaan, risiko sistimatik, set peluang investasi dan struktur aktiva berpengaruh terhadap kebijakan hutang.

\section{RERANGKA TEORITIS DAN PENGEMBANGAN HIPOTESIS}

\section{Teori Keagenan}

Teori keagenan merupakan basis teori yang mendasari praktik bisnis perusahaan yang dipakai selama ini. Teori tersebut berakar dari sinergi teori ekonomi, teori keputusan, sosiologi, dan teori organisasi. Prinsip utama teori ini menyatakan adanya hubungan kerja antara pihak yang memberi wewenang 
(prinsipal), yaitu investor dengan pihak yang menerima wewenang (agensi), yaitu manajer, dalam bentuk kontrak kerja sama yang disebut nexus of contract. Perbedaan kepentingan ekonomis ini bisa saja disebabkan ataupun menyebabkan timbulnya informasi asimetri (Kesenjangan informasi) antara Pemegang Saham (Stakeholders) dan organisasi. Deskripsi bahwa manajer adalah agen bagi para pemegang saham atau dewan direksi adalah benar sesuai teori agensi (Wahyudiharto 2009).

Teori keagenan mengasumsikan bahwa semua individu bertindak atas kepentingan mereka sendiri. Pemegang saham sebagai prinsipal diasumsikan hanya tertarik kepada hasil keuangan yang bertambah atau investasi mereka dalam perusahaan. Sedangkan para agen diasumsikan menerima kepuasan berupa kompensasi keuangan dan syarat-syarat yang menyertai dalam hubungan tersebut. Karena perbedaan kepentingan ini masing-masing pihak berusaha memperbesar keuntungan bagi diri sendiri. Prinsipal menginginkan pengembalian yang sebesar-besarnya dan secepatnya atas investasi yang salah satunya dicerminkan dengan kenaikan porsi dividen dari tiap saham yang dimiliki. Agen menginginkan kepentingannya diakomodasi dengan pemberian kompensasi/bonus/insentif yang memadai dan sebesar-besarnya atas kinerjanya. Prinsipal menilai prestasi agen berdasarkan kemampuannya memperbesar laba untuk dialokasikan pada pembagian dividen. Semakin tinggi laba, harga saham dan semakin besar dividen yang dibagikan, maka agen dianggap berkinerja dengan baik sehingga layak mendapat insentif yang tinggi (Wahyudiharto 2009).

Sebaliknya agensi-pun memenuhi tuntutan prinsipal agar mendapatkan kompensasi yang tinggi. Apabila tidak ada pengawasan yang memadai maka agensi dapat memainkan beberapa kondisi perusahan agar seolah-olah target tercapai. Permainan tersebut bisa atas prakarsa dari prinsipal ataupun inisiatif agen maka munculah creative accounting yang menyalahi aturan, misal adanya piutang yang tidak mungkin tertagih yang tidak dihapuskan, kapitalisasi expense yang tidak semestinya, pengakuan penjualan yang tidak semestinya yang berdampak pada besarnya nilai aktiva dalam neraca yang akan membuat laporan keuangan terlihat sangat baik walaupun tidak seperti keadaan yang sebenarnya. Melakukan income smoothing (membagi keuntungan ke periode lain) agar setiap tahun perusahaan terlihat meraih keuntungan, meskipun kenyataannya perusahaan merugi atau laba turun (Wahyudiharto 2009). 


\section{Kepemilikan Managerial dan Kebijakan Hutang}

Langkah memberikan bagian kepemilikan saham bagi para manajer ditujukan untuk (1) menarik dan mempertahankan manajer yang potensial dan (2) untuk mengarahkan tindakan manajer agar mendekati kepentingan pemegang saham, terutama untuk memaksimalkan harga saham. Para pemegang saham yang mempunyai kedudukan di manajemen perusahaan baik sebagai dewan komisaris atau direksi disebut sebagai kepemilikan managerial (Masdupi 2005).

Kepemilikan saham oleh pihak manajemen akan menimbulkan suatu pengawasan terhadap kebijakan yang diambil oleh manajemen perusahaaan. Termasuk kebijakan untuk menggunakan hutang. Pihak pemegang saham cenderung berkeinginan untuk mengurangi penggunaan hutang karena dengan banyaknya hutang akan meningkatkan risiko perusahaan.

Secara empiris hubungan struktur kepemilikan terhadap struktur modal dipengaruhi oleh aliran kas internal (Masdupi 2005). Ada dua teori yang dapat menjelaskan pengaruh yang berkaitan dengan aliran kas internal, yaitu pecking order hypothesis meniadakan hubungan antara pembelanjaan modal dan kepemilikan manajer dalam perusahaan, sedangkan managerial hypothesis menyatakan ada hubungan antara modal dan kepemilikan saham oleh manager.

Penelitian Nuringsih (2006), Putri dan Nasir (2006), Junaidi (2006) dan Masdupi (2005) menunjukkan bahwa kepemilikan managerial berpengaruh negatif terhadap kebijakan hutang. Sedangkan penelitian Murni dan Andriana (2007) serta Indahningrum dan Handayani (2009) menunjukkan kepemilikan managerial tidak memiliki pengaruh terhadap kebijakan hutang perusahaan. Berdasarkan managerial hypothesis dan hasil penelitian sebelumnya, maka hipotesis yang diajukan adalah:

$\mathrm{H}_{1}$ Kepemilikan managerial berpengaruh terhadap kebijakan hutang.

\section{Kepemilikan Institusional dan Kebijakan Hutang}

Kepemilikan institusional umumnya bertindak sebagai pihak yang memonitor perusahaan. Peningkatan aktivitas investor didukung oleh usaha mereka untuk meningkatkan tanggung jawab manajemen. Aktivitas pengawasan tersebut dapat dilakukan dengan menempatkan para komite penasehat (advisory committees) yang bekerja untuk melindungi kepentingan investor (Murni dan Andriana 2007).

Bentuk pengawasan lain adalah dengan cara memberikan masukanmasukan sebagai bahan pertimbangan bagi managerial dalam menjalankan usaha dan melalui rapat umum pemegang saham. Pada akhirnya, semakin 
besar presentase saham yang dimiliki oleh institutional akan menyebabkan usaha pengawasan menjadi lebih efektif karena dapat mengendalikan prilaku oportunistik manajer (Murni dan Andriana 2007).

Nuringsih (2006), Junaidi (2006) dan Wahidahwati (2002) membuktikan bahwa kepemilikan institusional berpengaruh negatif terhadap kebijakan hutang perusahaan, sedangkan penelitian Murni dan Andriana (2007) serta Indahningrum dan Handayani (2009) membuktikan bahwa kepemilikan institusional memiliki pengaruh yang positif signifikan terhadap kebijakan hutang perusahaan. Berdasarkan hasil penelitian sebelumnya, maka hipotesis yang diajukan adalah:

$\mathrm{H}_{2}$ Kepemilikan institusional berpengaruh terhadap kebijakan hutang.

\section{Kebijakan Dividen Kas dan Kebijakan Hutang}

Bagi para investor atau pemegang saham, dividen merupakan salah satu keuntungan yang akan diperolehnya selain keuntungan lain yang berupa capital gain. Secara umum dividen dapat diartikan sebagai bagian yang dibagikan oleh emiten kepada masing-masing pemegang saham. Kebijakan dividen ini akan memiliki pengaruh terhadap tingkat penggunaan utang suatu perusahaan. Kebijakan dividen yang stabil menyebabkan adanya keharusan bagi perusahaan untuk menyediakan sejumlah dana guna membayar jumlah dividen yang ditetapkan tersebut (Murni dan Andriana 2007).

Wahidahwati (2002) menyatakan bahwa pembayaran dividen adalah suatu bagian dari monitoring perusahaan. Dalam kondisi demikian, perusahaan cenderung untuk membayar dividen lebih besar jika pihak managemen memiliki proporsi saham yang lebih rendah. Pihak managemen akan menahan pembayaran dividen jika saham yang dimiliki oleh pihak managemen semakin banyak.

Perusahaan yang mempunyai dividend payout ratio tinggi akan menyukai pendanaan dengan modal sendiri (Fidyati 2003). Disamping itu, pembayaran dividen dapat dilakukan setelah kewajiban terhadap pembayaran bunga dan cicilan hutang dipenuhi. Hal ini akan membuat manager semakin berhati-hati dan efisien dalam menggunakan hutang.

Hasil penelitian Masdupi (2005) serta Murni dan Andriana (2007) serta Amirya dan Atmini (2008) menemukan bahwa adanya hubungan yang negatif dan signifikan antara kebijakan dividen dan kebijakan hutang. Sedangkan penelitian Fidyati (2003), Wahidahwati (2002) serta Indahningrum dan Handayani (2009) menunjukkan bahwa kebijakan dividen tidak menghasilkan pengaruh yang signifikan terhadap kebijakan hutang. Berdasarkan hasil penelitian sebelumnya, maka hipotesis yang diajukan adalah:

$\mathrm{H}_{3}$ Kebijakan dividen kas berpengaruh terhadap kebijakan hutang perusahaan. 


\section{Pertumbuhan Perusahaan dan Kebijakan Hutang}

Perusahaan yang memiliki tingkat pertumbuhan yang tinggi cenderung membutuhkan dana dari pihak eksternal yang lebih besar (Murni dan Andriana 2007). Untuk memenuhi kebutuhan dana dari luar, perusahaan dihadapkan pada pertimbangan sumber dana yang lebih murah. Dalam hal ini, penerbitan surat hutang lebih disukai dibanding dengan mengeluarkan saham baru karena biaya emisi saham baru lebih besar dari biaya hutang. Dengan demikian tingkat pertumbuhan yang tinggi cenderung lebih banyak menggunakan hutang sehingga dapat disimpulkan bahwa pertumbuhan perusahaan memiliki hubungan yang positif dan signifikan terhadap kebijakan hutang.

Perusahaan yang mempunyai investasi berupa aktiva tidak berwujud cenderung menggunakan sedikit hutang dalam struktur modal. (Murni dan Andriana 2007). Hasil penelitian Moh'd et al. (1998) menemukan bahwa pertumbuhan perusahaan memiliki pengaruh yang negatif dan signifikan terhadap kebijakan hutang. Sedangkan hasil penelitian Margaretha dan Asmariani (2009) menunjukkan bahwa pertumbuhan perusahaan berpengaruh positif terhadap kebijakan hutang. Penelitian Sihombing (2000) serta Indahningrum dan Handayani (2009) menghasilkan pertumbuhan perusahaan tidak memiliki pengaruh terhadap kebijakan hutang. Berdasarkan perbedaan hasil penelitian sebelumnya, maka hipotesis yang diajukan adalah:

$\mathrm{H}_{4}$ Pertumbuhan perusahaan berpengaruh terhadap kebijakan hutang.

\section{Profitabilitas dan Kebijakan Hutang}

Profitabilitas perusahaan merupakan kemampuan perusahaan dalam menghasilkan laba, yang merupakan penentu yang penting dari tingkat hutang perusahaan (Nurdin 2004). Perusahaan dengan rate of return yang tinggi cenderung menggunakan proporsi hutang yang relatif kecil, karena dengan rate of return yang tinggi, kebutuhan dana untuk pengembangan usaha atau investasi dapat diperoleh dari laba ditahan (Nurdin 2004).

Hasil penelitian Nurdin (2004) serta Indahningrum dan Handayani (2009) menyatakan bahwa tingkat profitabilitas memiliki hubungan yang negatif dan signifikan dengan kebijakan hutang. Rasio profitabilitas mem-berikan jawaban tentang efektivitas managemen dalam perusahaan. Rasio profitabilitas mengukur tingkat efektivitas dari managemen perusahaan melalui hasil yang dicapai perusahaan melalui penjualan dan investasi perusahaan. Perusahaan dengan tingkat pengembalian yang tinggi atas investasi menggunakan hutang yang relatif kecil. Dengan tingkat pengembalian yang tinggi memungkinkan perusahaan untuk membiayai sebagian besar pendanaan dengan dana internal dan cenderung menggunakan hutang yang relatif kecil. 
Perusahaan yang memiliki tingkat profitabilitas yang tinggi akan menghasilkan dana bagi perusahaan yang lebih banyak sehingga dapat digunakan bagi perusahaan sebagai penutup kewajiban atau pendanaan sehingga akan dapat berdampak pada berkurangnya tingkat penggunaan hutang oleh perusahaan atau dengan kata lain jika perusahaan profit maka perusahaan akan cenderung mengurangi rasio hutang mereka. Berdasarkan pemikiran tersebut, maka hipotesis yang diajukan adalah:

$\mathrm{H}_{5}$ Profitabilitas berpengaruh terhadap kebijakan hutang.

\section{Ukuran Perusahaan dan Kebijakan Hutang}

Perusahaan besar dapat mengakses pasar modal. Karena kemudahan tersebut maka berarti bahwa perusahaan memiliki fleksibilitas dan kemampuan untuk mendapatkan dana (Wahidahwati 2000). Semakin besar perusahaan tersebut maka semakin banyak dana yang digunakan untuk menjalankan operasional perusahaan. Salah satu sumber pendanaannya adalah dengan hutang.

Ukuran perusahaan menjadi faktor yang perlu dipertimbangkan dalam menentukan tingkat hutang perusahaan. Perusahaan-perusahaan besar cenderung lebih mudah untuk memperoleh pinjaman dari pihak ketiga, karena kemampuan mengakses kepada pihak lain atau jaminan yang dimiliki berupa aktiva bernilai lebih besar dibandingkan perusahaan kecil. Hasil penelitian Tarjo (2005) dan Prabowo (2006) menemukan adanya hubungan yang positif antara ukuran perusahaan dan kebijakan hutang. Berdasarkan hasil penelitian sebelumnya, maka hipotesis yang diajukan adalah:

$\mathrm{H}_{6}$ Ukuran perusahaan berpengaruh terhadap kebijakan hutang.

\section{Risiko Sistimatik terhadap Kebijakan Hutang}

Ada dua risiko yang dihadapi oleh perusahaan yaitu risiko sistimatik (systematic risk) dan risiko tidak sistimatik (unsystematic risk). Risiko tidak sistimatik merupakan risiko yang dapat didifersifikasi, sebaliknya risiko sistimatik merupakan risiko yang tidak dapat didifersifikasi. Risiko sistimatik disebut risiko pasar.

Jones (1996) menyatakan bahwa risiko sistematis diukur dengan beta yang merupakan suatu pengukur volatilitas return suatu sekuritas terhadap return pasar. Volatilitas merupakan fluktuasi dari return suatu sekuritas atau portofolio. Jika fluktuasi dari return sekuritas atau portofolio secara sistimatik mengikuti fluktuasi return pasar, maka beta dari sekuritas tersebut dikatakan bernilai satu. Hal ini menunjukkan bahwa risiko sistimatik suatu sekuritas atau portofolio sama dengan risiko pasar. Hasil penelitian Fidyati (2003) menyatakan bahwa risiko sistimatik mempunyai pengaruh negatif 
terhadap kebijakan hutang. Berdasarkan hasil penelitian sebelumnya, maka hipotesis yang diajukan adalah:

$\mathrm{H}_{7}$ Risiko sistimatik berpengaruh terhadap kebijakan hutang perusahaan.

\section{Set Peluang Investasi dan Kebijakan Hutang}

Peluang pertumbuhan terlihat pada peluang investasi yang diproksikan dengan bermacam kombinasi nilai set peluang investasi (IOS: Investment Opportunity Set) (Smith dan Watts 1992). Implikasi teori IOS berkaitan dengan keputusan pendanaan yang telah dilakukan perusahaan terdiri dari keputusan pendanaan jangka pendek, menengah dan jangka panjang. Smith dan Watts (1992) menemukan adanya bukti empiris bahwa pada perusahaan yang mempunyai peluang untuk bertumbuh lebih besar mempunyai rasio debt to equity yang lebih rendah dalam keputusan struktur modalnya. Pendanaan modal sendiri (equity financing) cenderung untuk mengurangi masalahmasalah keagenan, karena keberadaan hutang berisiko dalam struktur modalnya.

Prospek perusahaan yang bertumbuh bagi investor merupakan hal yang menguntungkan karena investasi yang ditanamkan diharapkan bisa memberikan return yang tinggi. Penelitian Vogt (1997) menunjukkan bahwa perusahaan yang sedang mengalami pertumbuhan akan direspon positif oleh pasar. Peluang pertumbuhan perusahaan terlihat pada peluang investasi yang diproksikan dengan kombinasi IOS. Berdasarkan hasil penelitian sebelumnya, maka hipotesis yang diajukan adalah:

$\mathrm{H}_{8}$ Set peluang bertumbuh berpengaruh terhadap kebijakan hutang.

\section{Struktur Aktiva dan Kebijakan Hutang}

Sebagian besar aktiva yang dimiliki perusahaan bentuknya nyata dalam bentuk aktiva tetap dan memiliki nilai likuiditas yang dapat dijual. Perusahaan dengan jumlah aktiva tetap yang lebih besar dapat memperoleh pinjaman yang lebih besar, karena aktiva tersebut digunakan sebagai jaminan yang lebih fleksibel daripada perusahaan yang struktur aktivanya tidak fleksibel. Kreditur akan selalu memberikan pinjaman apabila ada jaminannya. Aktiva tetap yang digunakan sebagai jaminan dapat mengurangi risiko kreditur, apabila perusahaan tidak mampu melunasi kewajibannya maka aktiva tersebut akan diambil alih dan dijual oleh kreditur sebagai bentuk pelunasan. Nilai aktiva tetap yang semakin besar dapat memberikan sinyal kepada kreditur untuk yakin memberikan pinjaman, karena kreditur akan terhindar dari risiko tidak terbayarkan pokok pinjaman maupun bunga apabila perusahaan dinyatakan bangkrut.

Hasil penelitian Margaretha dan Asmariani (2009), Harjito dan Nurfauziah (2006) serta Wahidahwati (2002) menunjukkan bahwa struktur 
aktiva berpengaruh terhadap kebijakan hutang. Sedangkan hasil penelitian Nurfauziah, et al. (2007), Sugiarto dan Budhijono (2007) dan Junaidi (2006) menunjukkan bahwa struktur aktiva tidak berpengaruh terhadap kebijakan hutang. Berdasarkan perbedaan hasil penelitian sebelumnya, maka hipotesis yang diajukan adalah:

$\mathrm{H}_{8}$ Struktur aktiva berpengaruh terhadap kebijakan hutang.

\section{METODE PENELITIAN}

\section{Pemilihan Sampel dan Pengumpulan Data}

Populasi dalam penelitian ini adalah semua perusahaan yang terdaftar di Bursa Efek Indonesia (BEI) dengan periode pengamatan 2005 sampai 2008. Pemilihan sampel dilakukan dengan menggunakan metoda purposive sampling, yaitu penelitian yang mempunyai tujuan atau target tertentu dalam memilih sampel secara tidak acak berdasarkan kriteria Adapun proses pemilihan sampel dapat dilihat pada tabel 1 berikut ini:

\section{Tabel 1 Proses Pemilihan Sampel}

\begin{tabular}{clc}
\hline No & \multicolumn{1}{c}{ Kriteria Sampel } & Jumlah \\
\hline 1 & $\begin{array}{l}\text { Perusahaan manufaktur yang terdaftar di BEI periode 2005-2008 } \\
2\end{array}$ & $\begin{array}{l}\text { Perusahaan manufaktur yang sahamnya tidak dimiliki oleh } \\
\text { institutional investor }\end{array}$ \\
3 & $\begin{array}{l}\text { Perusahaan manufaktur yang tidak mempunyai akhir tahun buku } \\
\text { per 31 Desember }\end{array}$ & $(2)$ \\
4 & Laporan keuangan dalam mata uang selain Rupiah \\
5 & $\begin{array}{l}\text { Perusahaan manufaktur yang tidak membagikan dividen secara } \\
\text { rutin dari tahun 2005-2008 }\end{array}$ & $(3)$ \\
6 & $\begin{array}{l}\text { Perusahaan manufaktur yang tidak memperoleh laba secara } \\
\text { konsisten dari tahun 2005-2008 }\end{array}$ & $(36)$ \\
7 & $\begin{array}{l}\text { Perusahaan manufaktur yang dapat dijadikan sampel } \\
8\end{array}$ & $\begin{array}{l}\text { Data penelitian tahun 2005 sampai 2008 } \\
9\end{array}$ \\
Data yang diolah & 38 \\
\hline
\end{tabular}

Data penelitian bersumber dari laporan keuangan auditan perusahaan manufaktur terdaftar di Bursa Efek Indonesia pada tahun 2005 sampai 2008, Fact Book 2006 sampai 2009, Ringkasan Kinerja Perusahaan, www.duniainvestasi.com dan BAPEPAM-LK. 


\section{Definisi Operasional dan Pengukuran Variabel}

Kebijakan hutang merupakan kebijakan untuk menentukan besarnya hutang yang ada dalam perusahaan agar perusahaan tetap stabil. Variabel ini diberi simbol DTA (Nurfauziah, et al. 2007). Kebijakan hutang dihitung dengan:

$$
\text { DTA }=\frac{\text { Long Term Debt }}{\text { Total Assets }}
$$

Kepemilikan managerial adalah para pemegang saham yang mempunyai kedudukan di managemen perusahaan baik sebagai dewan komisaris atau direktur (Masdupi 2005). Pengukuran variabel kepemilikan managerial menggunakan variabel dummy, kode 1 berarti terdapat saham yang dimiliki oleh pihak managerial sedangkan kode 0 tidak dimiliki.

Kepemilikan institusional (INST) merupakan tingkat kepemilikan saham oleh pihak outsider perusahaan dalam hal ini proporsi saham yang dimiliki institusional atau perusahaan lain (Murni dan Andriana 2007).

$$
\text { INST }=\frac{\text { Jumlah Saham Institusi }}{\text { Jumlah Saham Beredar }}
$$

Kebijakan dividen (DIV) diukur dengan dividend payout ratio, yaitu rasio pembayaran dividen terhadap earnings after tax. Rasio ini menggambarkan kebijakan dividen perusahaan (Wahidahwati 2002).

$$
\mathrm{DIV}=\frac{\text { Dividend }}{\text { Earnings after tax }}
$$

Pertumbuhan perusahaan (GROW) diukur dengan menghitung tingkat pertumbuhan total aktiva (Murni dan Andriana 2007).

$$
\text { GROW }=\frac{\text { (Aktiva Akhir Tahun }- \text { Aktiva Awal Tahun) }}{\text { Aktiva Awal Tahun }}
$$

Profitabilitas adalah kemampuan perusahaan untuk menghasilkan laba, tingkat profitabilitas diukur dengan menggunakan rata-rata tingkat pengembalian atas aset ROA (Return on Assets) (Nurdin 2004).

$$
\mathrm{ROA}=\frac{\text { Earnings After } T a x}{\text { Assets }}
$$

Ukuran perusahaan (SIZE) adalah kekayaan perusahaan diukur dari total aktiva perusahaan (Fidyati 2003).

$$
\text { SIZE }=\text { Log }(\text { Total Aktiva })
$$


Risiko sistimatik diukur dengan beta $(\beta)$ yang merupakan suatu pengukur volatilitas (merupakan fluktuasi dari return suatu sekuritas atau portofolio) return suatu sekuritas terhadap return pasar. Dalam penelitian ini beta dihitung dengan menghitung return ekspektasi yang dikoreksi untuk memperoleh beta yang sebenarnya (Fidyati 2003). Secara matematis dapat dirumuskan sebagai berikut:

$\beta=\frac{\operatorname{Covar}(R j \cdot R m)}{\operatorname{Var}(R m)}$

$\operatorname{Covar}(\mathrm{Rj} . \mathrm{Rm})=\frac{\sum(\mathrm{Rj}-\overline{\mathrm{R}})(\mathrm{Rm}-\overline{\mathrm{Rm}})}{n-1}$

$\operatorname{Var}(\mathrm{Rm})=\frac{\sum(\mathrm{Rm}-\overline{\mathrm{Rm}})^{2}}{n-1}$

$\mathrm{Rm}=\frac{\mathrm{Yt}-\mathrm{Yt}-1}{\mathrm{Yt}-1}$

$\mathrm{Rj}=\frac{\mathrm{Xt}-\mathrm{Xt}-1}{\mathrm{Xt}-1}$

Keterangan $\beta$ Risiko Sistematis, Rm Return market, Rj Return emiten, Y Indeks harga saham gabungan, $X$ harga saham perusahaan.

Set peluang investasi IOS (Investment Opportunity Set) menggunakan proksi ratio earnings per share $(\mathrm{E} / \mathrm{P})$ sebagai dasar untuk mengukur IOS karena rasio E/P dapat menunjukkan adanya aliran laba di masa depan dan merupakan salah satu proksi potensi pertumbuhan yang valid (Tumanggor 2002).

$\mathrm{E} / \mathrm{P}=\frac{\text { Earnings Per Share }}{\text { Harga jual saham }}$

\section{Teknik Analisis}

Dalam penelitian ini metoda yang digunakan dalam menganalisis data adalah regresi berganda. Persamaan regresi yang digunakan adalah:

$$
\begin{aligned}
\text { DTE }= & b_{0}+b_{1}(\text { INSD })+b_{2}(\text { INST })+b_{3}(\text { DIV })+b_{4}(\text { GROW })+b_{5}(\text { ROA })+ \\
& b_{6}(\text { SIZE })+b_{7}(\beta)+b_{8}(\text { IOS })+b_{9}(\text { SA })+e
\end{aligned}
$$

Keterangan: DTE Kebijakan Hutang, INSD Kepemilikan Managerial, INST Kepemilikan Institusional, DIV Kebijakan Dividen, GROW Pertumbuhan Perusahaan, ROA Profitabilitas, SIZE Ukuran Perusahaan, $\beta$ Risiko Sistimatik, IOS Set Peluang Investasi, SA Struktur Aset, e Error 


\section{HASIL PENELITIAN}

Statistik deskriptif ini digunakan untuk memberikan gambaran nilai minimum, maksimum, rata-rata (mean), dan simpangan baku (standard deviation) dari variabel-variabel yang diteliti. Hasil deskriptif dapat dilihat pada tabel 2 berikut ini:

Tabel 2 Statistika Deskriptif

\begin{tabular}{lccccc}
\hline Variabel & $\mathbf{N}$ & Minimum & Maximum & Mean & Std. Deviation \\
\hline MO & 141 & 0 & 1 & 0,3600 & 0,4820 \\
IO & 141 & 0,1300 & 0,98 & 0,7263 & 0,1915 \\
DIV & 141 & 0,0300 & 3,83 & 0,4099 & 0,5315 \\
GROW & 141 & 0 & 1 & 0,8700 & 0,3430 \\
ROA & 141 & 0,0028 & 0,39 & 0,0922 & 0,0706 \\
SIZE & 141 & 10,6200 & 13,91 & 12,0538 & 0,6629 \\
BETA & 141 & $5 \mathrm{e}-007$ & 5,09 & 0,3758 & 0,7202 \\
IOS & 141 & 0,0200 & 1,17 & 0,2779 & 0,2145 \\
SA & 141 & 0,0075 & 0,90 & 0,3228 & 0,1689 \\
DTE & 141 & 0,0029 & 0,38 & 0,1092 & 0,0990 \\
\hline
\end{tabular}

Tabel 3 Hasil Pengujian Hipotesis

\begin{tabular}{lrrccc}
\hline Variabel & \multicolumn{1}{c}{$\mathbf{B}$} & \multicolumn{1}{c}{ T } & p-value & Tolerance & VIF \\
\hline Konstanta & $-0,439$ & $-3,372$ & 0,001 & & \\
MO & $-0,036$ & $-2,427$ & 0,017 & 0,756 & 1,322 \\
IO & 0,032 & 0,891 & 0,375 & 0,799 & 1,251 \\
DIV & $-0,023$ & $-1,912$ & 0,058 & 0,965 & 1,036 \\
GROW & $-0,008$ & $-0,405$ & 0,686 & 0,911 & 1,097 \\
ROA & $-0,479$ & $-4,674$ & 0,000 & 0,731 & 1,369 \\
SIZE & 0,047 & 4,382 & 0,000 & 0,773 & 1,294 \\
BETA & 0,001 & 0,143 & 0,887 & 0,931 & 1,074 \\
IOS & $-0,115$ & $-3,429$ & 0,001 & 0,747 & 1,339 \\
SA & 0,209 & 5,360 & 0,000 & 0,881 & 1,136 \\
\hline
\end{tabular}

Adjusted $\mathrm{R}^{2} \quad 0,452 ; \mathrm{F}_{9,131} 13,820$ p-value: 0,000; Kolmogorov-Smirnov $Z$ residual: 0,928 -value: 0,355

Berdasarkan tabel 3 di atas, variabel kepemilikan managerial memiliki p-value 0,017 di bawah 0,05 maka $\mathrm{H}_{1}$ terdukung, artinya variabel kepemilikan managerial berpengaruh terhadap kebijakan hutang. Hasil penelitian ini menunjukkan bahwa kepemilikan saham oleh pihak managerial membuat manager menerima konsekuensi secara langsung dari setiap keputusan yang 
dibuat. Semakin besar kepemilikan managerial maka manager cenderung berusaha untuk meningkatkan kinerjanya demi kepentingan pemegang saham termasuk dirinya sendiri.

Kepemilikan institusional memiliki p-value 0,375 maka $\mathrm{H}_{2}$ tidak terdukung, artinya kepemilikan institusional tidak berpengaruh terhadap kebijakan hutang. Besarnya presentase saham yang dimiliki oleh pihak institusional tidak akan menyebabkan usaha pengawasan menjadi lebih efektif. Sebagian investor tidak terlalu perduli dengan penggunaan hutang sebagai sumber dana perusahaan. Mereka lebih memperhatikan hasil akhir, yaitu perusahaan memiliki kinerja yang bagus yang dilihat dari laba, aliran kas masuk operasi dan kemampuan membayar hutang.

Kebijakan dividen memiliki p-value 0,058 di bawah 0,10 maka dapat disimpulkan $\mathrm{H}_{3}$ terdukung, artinya kebijakan dividen berpengaruh terhadap kebijakan hutang. Pembayaran dividen kas akan mengurangi sumber dana yang dikendalikan managemen seperti hutang. Perusahaan yang membayar dividen kas mengindikasikan bahwa perusahaan mampu membiayai peluang investasi tanpa menggunakan sumber dana eksternal seperti hutang.

Pertumbuhan perusahaan memiliki p-value 0,686 maka dapat disimpulkan $\mathrm{H}_{4}$ tidak terdukung, artinya pertumbuhan perusahaan tidak berpengaruh terhadap kebijakan hutang. Tingkat pertumbuhan perusahaan yang tinggi tidak cenderung banyak menggunakan hutang untuk memenuhi kebutuhan dana. Pertumbuhan perusahaan dengan bertambahnya aktiva tidak semuanya berasal dari hutang, karena perusahaan lebih cenderung untuk menghindari risiko apabila tidak mampu melunasinya.

Profitabilitas memiliki p-value 0,000 di bawah 0,05 maka $\mathrm{H}_{5}$ terdukung, artinya profitabilitas berpengaruh terhadap kebijakan hutang. Perusahaan yang mampu menghasilkan laba maka untuk memenuhi sumber pendanaan lebih cenderung menggunakan laba ditahan untuk menghindari risiko dibanding menggunakan hutang. Pada saat perusahaan menghasilkan laba yang rendah, cenderung menggunakan hutang sebagai mekanisme transfer kekayaan dari kreditur ke perusahaan.

Ukuran perusahaan memiliki p-value 0,000 di bawah 0,05 maka $\mathrm{H}_{6}$ terdukung, artinya ukuran perusahaan berpengaruh terhadap kebijakan hutang. Perusahaan yang besar lebih cenderung mudah mendapatkan pinjaman dari pihak kreditur, karena informasi mengenai kondisi internal perusahaan lebih mudah diperoleh.

Risiko sistimatik memiliki p-value 0,887 maka $\mathrm{H}_{7}$ tidak terdukung, artinya risiko sistimatik tidak berpengaruh terhadap kebijakan hutang. Hal ini tidak menunjukan bahwa perusahaan yang mempunyai risko sistimatik tinggi akan kesulitan mencari sumber dana dari pihak luar berupa hutang. Perusahaan yang menghadapi risiko pasar lebih cenderung untuk tidak menggunakan hutang sebagai sumber pendanaan. 
Set peluang investasi memiliki p-value 0,001 di bawah 0,05 maka $\mathrm{H}_{8}$ terdukung, artinya set peluang investasi berpengaruh terhadap kebijakan hutang. Peluang pertumbuhan perusahaan terlihat pada peluang investasi. Perusahaan yang yang memiliki peluang bertumbuh lebih cenderung menggunakan sumber dana berasal dari laba ditahan dan modal saham daripada pinjaman yang mengandung risiko.

Struktur aktiva memiliki p-value 0,000 di bawah 0,05 maka $_{9}$ terdukung, artinya struktur aktiva berpengaruh terhadap kebijakan hutang. Semakin tinggi struktur aktiva perusahaan maka perusahaan akan lebih mudah mendapatkan pinjaman dengan jaminan berupa aktiva tetap.

\section{PENUTUP}

Kepemilikan managerial berpengaruh terhadap kebijakan hutang. Hasil ini konsisten dengan penelitian Nuringsih (2006), Putri dan Nasir (2006), Junaidi (2006) dan Masdupi (2005). Sedangkan kepemilikan institusional tidak berpengaruh terhadap kebijakan hutang. Hasil penelitian ini konsisten dengan Penelitian D.L, (2004) serta Putri dan Nasir (2006). Hasil ini tidak konsisten dengan penelitian Wahidahwati (2002), Nuringsih (2006), Junaidi (2006), Murni dan Andriana (2007) serta Indahningrum dan Handayani (2009).

Kebijakan dividen kas berpengaruh terhadap kebijakan hutang. Hasil ini konsisten dengan penelitian Ismiyanti dan Hanafi (2003), Murni dan Andriana (2007) serta Amirya dan Atmini (2008). Sedangkan pertumbuhan perusahaan tidak berpengaruh terhadap kebijakan hutang. Hasil ini tidak konsisten dengan penelitian Margaretha dan Asmariani (2009) serta Murni dan Andriana (2007).

Profitabilitas berpengaruh terhadap kebijakan hutang. Hasil ini konsisten dengan penelitian Ismiyanti dan Hanafi (2003), Nurdin (2004), Sugiarto dan Budhijono (2007), Amirya dan Atmini (2008) serta Indahningrum dan Handayani (2009). Begitu juga, ukuran perusahaan berpengaruh terhadap kebijakan hutang. Hasil ini konsisten dengan penelitian Tarjo (2005) dan Prabowo (2006).

Risiko sistimatik tidak berpengaruh terhadap kebijakan hutang. Hasil ini tidak konsisten dengan penelitian Fidyati (2003). Sedangkan set peluang investasi berpengaruh terhadap kebijakan hutang. Hasil ini konsisten dengan penelitian Tumanggor (2002), Bukhori (2005) dan Ratnawati (2007).

Struktur aktiva berpengaruh terhadap kebijakan hutang. Hasil penelitian ini konsisten dengan penelitian Margaretha dan Asmariani (2009), Harjito dan Nurfauziah (2006) serta Wahidahwati (2002).

Penelitian ini dapat memberikan masukan bagi para manager keuangan dalam pengambilan keputusan pendanaan untuk memperhatikan kepemilikan 
saham oleh pihak managerial, dividen kas yang akan dibagikan, tingkat keuntungan, ukuran perusahaan, set peluang investasi dan struktur aktiva perusahaan. Manager yang memiliki saham pada perusahaannya cenderung menggunakan dana berasal dari laba ditahan dan modal saham sehingga mereka akan membagikan dividen kas untuk menarik pihak investor membeli saham perusahaan. Sumber dana yang berasal dari hutang memberikan risiko bagi perusahaan apabila saat jatuh tempo perusahaan tidak mampu melunasi. Manager lebih senang menggunakan sumber dana dari laba ditahan dan modal saham, karena memiliki risiko yang kecil. Perusahaan yang menghasilkan laba yang besar akan menggunakan laba tersebut sebagai sumber pendanaan dan menarik investor dengan membagikan dividen kas. Laba tersebut menunjukkan seberapa besar set peluang investasi, aliran dana baik sekarang maupun yang akan datang untuk digunakan dalam mengembangkan perusahaan khususnya pembelian aktiva tetap.

Sebelum membeli saham perusahaan, investor akan melihat bagaimana sumber pendanaan perusahaan apakah lebih cenderung menggunakan hutang atau modal saham. Investor lebih cenderung membeli saham pada perusahaan yang menghasilkan laba, karena perusahaan akan cenderung menggunakan dana dari laba ditahan dan modal saham serta memiliki risiko yang kecil akan kebangkrutan.

Untuk peneliti selanjutnya dengan memperhatikan beberapa hal sebagai berikut (1) menambah sampel pada perusahaan non manufaktur dan lembaga keuangan sehingga diharapkan dapat memberikan hasil penelitian yang berbeda, (2) memperpanjang periode pengamatan agar dapat mencakup keseluruhan kondisi yang terjadi di Bursa Efek Indonesia dan (3) menambah variabel independen, seperti peluang bertumbuh dan securable asset.

\section{REFERENSI:}

Amirya, Mirna dan Sari Atmini. 2008. Determinan tingkat Hutang sert Hubungan tingkat Hutang terhadap Nilai Perusahaan: Perspektif Pecking Order Theory. Jurnal Akuntansi dan Keuangan Indonesia, Vol. 5, No. 2.

Bukhori, Iskandar. 2005. Pengaruh Kepemilikan Saham Institusional dan Investment Opportunity Set terhadap Kebijakan Hutang. Utilitas, Vol. 13, No. 2.

D.L, Wuryaningsih. 2004. Pengujian Pengaruh Capital Structure pada Debt Policy (Studi empiris pada Perusahaan manufaktur di Indonesia). Benefit, Vol. 8, No. 2, Hlm. 139-150.

Fidyati, Nisa. 2003. Faktor-faktor yang Mempengaruhi Kebijakan Hutang Perusahaan Publik di Indonesia. Jurnal Ekonomi Manajemen dan Akuntansi, Vol. 1, No. 1.

Harjito, D. Agus dan Nurfauziah. 2006. Hubungan Kebijakan Hutang, Insider Ownership dan Kebijakan Dividen dalam Mekanisme Pengawasan Masalah Agensi di Indonesia. Jurnal Akuntansi dan Auditing Indonesia, Vol. 10, No. 2, Hlm. 161-182. 
Indahningrum, Rizka Putri dan Ratih Handayani. 2009. Pengaruh Kepemilikan Managerial, Kepemilikan Institusional, Dividen, Pertumbuhan Perusahaan, Free Cash Flow dan Profitabilitas terhadap Kebijakan Hutang Perusahaan. Jurnal Bisnis dan Akuntansi, Vol. 11, No. 3, Hlm. 189-207.

Ismiyanti, Firti dan Mamduh M. Hanafi. Kepemilikan Manajerial, Kepemilikan Institusional, Risiko, Kebijakan Hutang dan Kebijakan Dividen: Analisis Persamaan Simultan. Prosiding, Simposium Nasional Akuntansi 6, Surabaya.

Junaidi. 2006. Pengaruh Kepemilikan Manajerial dan Kepemilikan Institusional terhadap Kebijakan Hutang Perusahaan: Sebuah Perspektif Agency Theory dengan Variabel Kontrol Dividend Payout Ratio, Ukuran Perusahaan, Asset Structure dan Risiko Bisnis (Studi pada Perusahaan yang go public di Bursa Efek Jakarta). Jurnal Ilmiah Bidang Manajemen \& Akuntansi, Vol. 3, No. 2.

Margaretha, Farah dan Andhini Asmariani. 2009. Faktor-faktor Agency Theory yang mempengaruhi Hutang. Media Riset Bisnis \& Manajemen, Vol. 9, No. 1, Hlm. 1-20.

Masdupi, Erni. 2005. Analisis Dampak Struktur Kepemilikan pada Kebijakan Hutang dalam Mengontrol Konflik Keagenan. Jurnal Ekonomi dan Bisnis. Vol. 20, No. 1, Hlm. 57-69.

Murni, Sri dan Andriana. 2007. Pengaruh Insider Ownership, Institutional Investor, Dividen Payments, dan Firm Growth terhadap Kebijakan Hutang Peruahaan (Studi Kasus pada Perusahaan Manufaktur yang Terdaftar di Bursa Efek Jakarta), Jurnal Akuntansi dan Bisnis, Vol. 7. No. 1, Hlm. 15-24.

Nurdin. 2004. Pengaruh Resiko Bisnis, Profitabilitas, Pertumbuhan dan Securable Asset terhadap Tingkat Leverage Perusahaan. Performa, Vol. 1, No. 1.

Nurfauziah, D. Agus Harjito, Hertya Dwi Ameliawati.2007. Hubungan Kepemilikan Manajerial, Kepemilikan Institusi dan Kebijakan Hutang dalam Prespektif Masalah Agency di Indonesia, Ventura, Vol. 10, No. 1.

Nuringsih, Kartika. 2006. Analisis Pengaruh Struktur Kepemilikan terhadap Kebijakan Dividen dan Hutang dalam Mengontrol Konflik Keagenan. Jurnal Ekonomi, Vol. 11, No. 3.

Prabowo, Tripitono Adi. 2006. Analisis Pengaruh Investasi terhadap Hutang pada Perusahaan Manufaktur yang Listed di Bursa Efek Jakarta. Media Trend, Vol. 1, No. 1, Hlm. 24-30.

Putri, Imanda Firmantyas dan Mohammad Nasir. 2006. Analisis Persamaan Simultan Kepemilikan Manajerial, Kepemilikan Institusional, Risiko, Kebijakan Hutang dan Kebijakan Dividen dalam Perspektif Teori Keagenan. Prosiding, Simposium Nasional Akuntansi 9, Padang.

Sugiarto dan Fongnawati Budhijono. 2007. Telaahan Indikasi Keagenan pada Kebijakan Leverage Perusahaan Kelaurga Di BEJ. Akuntabilitas, Vol. 6, No. 2, Hlm. 165178.

Tarjo. 2005. Analisa Free Cash Flow dan Kepemilikan Manajerial Terhadap Kebijakan Hutang pada Perusahaan Publik di Indonesia. Jurnal Riset Akuntansi Indonesia. Vol. 8, No. 1.

Tumanggor, M. S. 2002. Keterkaitan antara Investment Opportunity Set (IOS) dengan Pendanaan dan Dividen Perusahaan pada Pasar sedang Berkembang. Jurnal Manajemen. Vol. 5, No. 1.

Wahidahwati. 2002. Pengaruh Kepemilikan Manajerial dan Kepemilikan Institusional pada Kebijakan Hutang Perusahaan: sebuah perspektif theory agency. Jurnal Riset Akuntansi Indonesia. Vol. 5. No. 1. 